\title{
EFFECT OF ANAESTHESIA AND SURGERY ON ENDOCRINE FUNCTION IN ELDERLY PATIENTS
}

\author{
T. Oyama, K. Taniguchi, T. Takazawa, A. Matsuki and M. Kudo
}

\begin{abstract}
The effect of halothane-nitrous oxide anaesthesia and abdominal surgery on endocrine function was investigated in 18 elderly patients whose ages ranged from 65 to 77 (mean 69 years).

Cortisol levels in plasma increased significantly during anaesthesia and surgery, and the increases were slightly higher than those in young adults. Plasma aldosterone increased and insulin levels did not change during the procedures, and these levels were lower than in younger adults.

The endocrine responses in elderly patients were similar in magnitude to those in young adults. Therefore it appears that no special hormonal treatment is necessary for elderly patients undergoing routine surgical procedures.
\end{abstract}

MANY STUdies aRE AVAlLable on the effect of anaesthesia and surgery on the endocrine function in adults. ${ }^{1-5}$ Although the number of elderly patients submitted to operation has increased, no information is available on endocrine responses in these patients. The present investigation was undertaken to determine whether or not hormonal responses in the elderly are different from those in younger adults, because the hormonal function might play a role in the perioperative and postoperative metabolic responses of surgical patients.

\section{METhoDs}

Eighteen patients of either sex ranging in age from 65 to 77 years, (mean $69 \pm 0.9$ years) served as subjects of this study. ASA classifications were 1 or 2, and none of the patients had any abnormality of endocrine, hepatic or renal function. All of them underwent abdominal operations. Premedication consisted of pentobarbitone $50 \mathrm{mg}$, meperidine $35 \mathrm{mg}$ and atropitie $0.5 \mathrm{mg}$ given 1.5 hours before the start of anaesthesia. Anaesthesia was induced with halothane, nitrous oxide and oxygen, and the operation was not started until 20 minutes after induction.

The trachea was intubated after the first blood sample had been obtained and following intravenous injection of succinylcholine chloride $40 \mathrm{mg}$. Thereafter anaesthesia was maintained with halothane $(0.5-1.0$ per cent), nitrous oxide

T. Oyama, M.D., K. Taniguchi, M.D., T. Takazawa, M.D., A. Matsuki, M.D., M. Kudo, M.D., Department of Anesthesiology, University of Hirosaki, School of Medicine, Hirosaki, Japan.
$2 \mathrm{~L} \cdot \min ^{-1}$ and oxygen $2 \mathrm{~L} \cdot \mathrm{min}^{-1}$ and d-tubocurarine 3-6 mg was injected when needed.

Abdominal operations which started after 1330 hours were selected because of consideration for diurnal variations in plasma concentrations of hormones. The patients received no food for 10 hours before the start of procedure, and $500 \mathrm{ml}$ of dextrose five per cent were infused intravenously over three hours before noon. Infusion of lactated Ringer's solution 6-7 $\mathrm{ml} \mathrm{kg}^{-1} /$ hour was started just before induction and continued throughout the procedure. Blood was transfused when blood loss exceeded $300 \mathrm{~g}$.

A five $\mathrm{ml}$ blood sample was obtained at the following five stages: (1) just before induction of anaesthesia, (2) 20 minutes after the start of anaesthesia but before the operation was begun, (3) 30 minutes after, and (4) one hour after the start of the operation and (5) in the recovery room when the patients had recovered adequately from anaesthesia. Plasma separated immediately after sampling was kept at $-20^{\circ} \mathrm{C}$ until the determination of the hormones. Arterial blood for the determination of blood gases and electrolytes was obtained at (1) just before induction, (2) 30 minutes after the start of the operation, and (3) in the recovery room when the patient was awake.

Plasma concentration of cortisol was determined by Rudd's fluorimetric method. ${ }^{6}$ Plasma concentrations of aldosterone, growth hormone and insulin were determined by the radioimmunoassay methods of Mayers, et al.,? Schalch and Parker, ${ }^{8}$ and Moran and Lazarow, ${ }^{9}$ respectively. The recovery rates were 85 percent for aldosterone, 98 per cent for growth hormone and 94 per cent for insulin. 


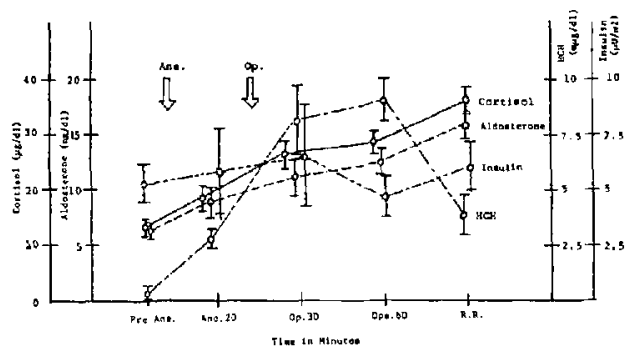

Figure I Plasma levels of cortisol, aldosterone, growth hormone (HOH) and insulin during halothane$\mathrm{N}_{2} \mathrm{O}$ anesthesia and surgery in elderly patients.

\section{Results}

\section{Plasma cortisol}

Plasma concentration of cortisol immediately before the induction of anaesthesia was 13.8 \pm $0.9 \mu \mathrm{g} \cdot \mathrm{dl}^{-1}(\mathrm{M} \pm \mathrm{SE})$. It increased significantly $(\mathrm{p}<0.05)$ to $18.8 \pm 2.3 \mu \mathrm{g} \cdot \mathrm{dl}^{-1}$ after 20 minutes of halothane-nitrous oxide anaesthesia alone and then continued to rise further until patients were awake (Figure 1).

\section{Plasma aldosterone}

Aldosterone concentration in plasma just before the induction of anaesthesia was $6.2 \pm 0.2$ $\mathrm{ng} \cdot \mathrm{dl}^{-1}(\mathrm{M} \pm \mathrm{SE})$. It increased significantly $(\mathrm{p}<$ $0.05)$ to $9.01 \pm 1.0 \mathrm{ng} \cdot \mathrm{dl}^{-1}$ after 20 minutes of anaesthesia alone, as shown in Figure 1. There- after it increased further into the postoperative period, similar to cortisol.

\section{Plasma Growth Hormone and Insulin}

Growth hormone level in plasma before induction of anaesthesia was $0.7 \pm 0.1 \mathrm{~m} \mu \mathrm{g} \cdot \mathrm{dl}^{-1}(\mathrm{M} \pm$ $\mathrm{SE}$ ); it increased to $2.5 \pm 0.9 \mathrm{m \mu g} \cdot \mathrm{dl}^{-1}$ during anaesthesia alone, which was not a statistically significant elevation. However, it increased significantly to $8.0 \pm 8.9 \mathrm{m \mu g} \cdot \mathrm{dl}^{-1}$ during operation and then decreased gradually (Figure 1).

Plasma concentration of insulin before the induction of anaesthesia was $5.2 \pm 0.9 \mu \mathrm{U} \cdot \mathrm{ml}^{-1}$, which did not change during anaesthesia or operation (Figure 1).

\section{Blood gases and electrolytes}

Blood gases did not change significantly during anaesthesia or operation, but a slight tendency to metabolic acidosis was noted during the recovery period. Serum sodium concentration decreased slightly during anaesthesia and operation and in the postoperative period. However, no change in plasma potassium concentration was found during the procedure, as shown in Table $\mathbf{I}$.

\section{Discussion}

Although the number of geriatric surgical patients has been increasing and the effects of anaesthesia and operation on respiratory and

TABLE I

Blood Gas analysis and Serum Sodium and Potassium Concentrations During Halothane Nitrous Oxide anaestitesia and Operation IN ELderly Patients

\begin{tabular}{|c|c|c|c|}
\hline & Pre-Anaes. & Oper. $30^{\prime}$ & R.R.* \\
\hline $\begin{array}{l}\mathrm{cH}^{+} \mathrm{nmol} / 1 \\
(\mathrm{pH})\end{array}$ & $\begin{array}{l}39.81 \pm 0.91 \\
(7.40 \pm 0.01)\end{array}$ & $\begin{array}{l}38.90 \pm 0.89 \\
(7.41 \pm 0.01)\end{array}$ & $\begin{array}{l}42.66 \pm 0.98 \\
(7.37 \pm 0.01)\end{array}$ \\
\hline $\begin{array}{l}\mathrm{Pa}_{\mathrm{Co}_{2}}(\mathrm{kPa}) \\
(\mathrm{mm} \mathrm{Hg})\end{array}$ & $\begin{array}{r}5.01 \pm 0.11 \\
(37.7 \pm 0.8)\end{array}$ & $\begin{array}{r}4.71 \pm 0.19 \\
(35.4 \pm 1.4)\end{array}$ & $\begin{array}{r}5.20 \pm 0.19 \\
(39.1 \pm 1.4)\end{array}$ \\
\hline $\begin{array}{l}\mathrm{Pa}_{2}(\mathrm{kPa}) \\
\quad(\mathrm{mm} \mathrm{Hg})\end{array}$ & $\begin{array}{l}11.53 \pm 0.31 \\
(86.7 \pm 2.3)\end{array}$ & $\begin{array}{c}27.15 \pm 1.24 \\
(204.1 \pm 9.3)\end{array}$ & $\begin{array}{r}34.63 \pm 2.78 \\
(260.4 \pm 20.9)\end{array}$ \\
\hline $\begin{array}{l}\mathrm{HCO}_{3}^{-} \\
(\mathrm{mmol} / 1)\end{array}$ & $22.9 \pm 0.4$ & $22.6 \pm 0.3$ & $21.8 \pm 0.5$ \\
\hline B.E. & $-1.2 \pm 0.3$ & $-1.8 \pm 0.3$ & $-3.0 \pm 0.4$ \\
\hline $\begin{array}{l}\mathrm{Na}^{+} \\
(\mathrm{mmol} / \mathrm{l})\end{array}$ & $138.7 \pm 0.6$ & $136.0 \pm 0.3$ & $134.0 \pm 0.7$ \\
\hline $\begin{array}{l}\mathbf{K}^{+} \\
(\mathrm{mmol} / \mathrm{l})\end{array}$ & $3.9 \pm 0.1$ & $3.9 \pm 0.1$ & $3.8 \pm 0.1$ \\
\hline
\end{tabular}

*: in the recovery room.

Figures denote mean \pm S.E. 
cardiovascular functions have been investigated extensively, little information is available regarding their effect on endocrine function in elderly patients.

It is important to know whether or not the aging process modifies the acute stress response, since changes might affect the outcome in the perianaesthetic and post-anaesthetic periods.

Plasma cortisol levels in geriatric patients in the pre-anaesthesia period were comparable to those in young adults, which is in accord with the report of Jensen and Blichert-Toft. ${ }^{10}$ During halothane anaesthesia and operation cortisol increased significantly and was slightly higher than in young adults. ${ }^{11.12}$ Our results do not imply that adrenocortical function is stimulated more in elderly patients than in young adults. Rather it would be a decreased metabolic clearance rate of cortisol in older patients which results in relatively high plasma levels, both during and after operation.

Plasma aldosterone concentration just before anaesthesia was $6.2 \pm 0.2 \mathrm{ng} \cdot \mathrm{dl}^{-1}$, which is close to the lower limit of the normal range for young aduits $\left(5.7-14.6 \mathrm{ng} \cdot \mathrm{dl}^{-1}\right)$. Aldosterone levels during anaesthesia and operation were lower than those in young adults which we have reported previously. ${ }^{13}$ This would suggest that, although the adrenal cortex in elderly patients responds to anaesthesia and operation, the response was slightly weaker than in young adults.

Growth hormone level in plasma in the preanaesthesia period was low, and was barely one-third of that found in our young adults. However, in response to the anaesthesia and operation it increased as much as in young adults. ${ }^{14}$

Insulin concentration was low in plasma in elderly patients and was almost half of that in our young adults. ${ }^{14}$ As in young adults there were no marked changes in plasma insulin levels during anaesthesia and operation. ${ }^{14}$

Blood gas and electrolyte changes during anaesthesia and operation showed a tendency similar to those observed in young adults. As in young adults no metabolic alkalosis or hypokalaemia due to hypersecretion of aldosterone were observed.

Although these observations indicate that the pre-anaesthetic plasma levels of aldosterone, growth hormone and insulin are lower in the elderly than in young adults, the plasma concentrations of these hormones responded to anaesthesia and operation as in young adults. No marked metabolic or electrolyte deviation was found, as compared with young adults. These findings indicate that, so far as the parameters studied are concerned, the range of endocrine response to anaesthesia and operation in old patients is similar to that in young adults. Therefore no special hormonal treatment is indicated for routine non-endocrine surgical procedures. However, the hormonal response to extremely prolonged anaesthesia and operation was not determined. Therefore a further study will be necessary to determine hormonal response to severe stress.

\section{REFERENCES}

1. Oyama, T., Shibata, S., Matsumoto, F., Matsuki, A., Kimura, K. \& Tamazawa, T. Adrenocortical function related to methoxyflurane anaesthesia and surgery in man. Canad. Anaesth. Soc. J. 15: 362 (1968).

2. Oyama, T. \& Takiguchi, M. Effects of neuroleptanaesthesia on plasma levels of growth hormone and insulin. Brit. J. Anaesth. 42: 1105 (1970).

3. Oyama, T., Takiguchi, M. \& Sato, K. Effects of droperidol-pentazocine- $\mathrm{N}_{2} \mathrm{O}$ anaesthesia on adrenocortical function in man. Canad. Anaesth. Soc. J. 18: 298 (1971).

4. Oyama, T., Takiguch, M. \& Kudo, T. Metabolic effects of anaesthesia: effect of thiopentone-nitrous oxide anaesthesia on human growth hormone and insulin levels in plasma. Canad. Anaesth. Soc. J. 18: 442 (1971).

5. Oyama, T., Taniguchi, K., Ishihara, H. Matsuki, A., Maeda, A., Murakawa, T. \& Kudo, $T$. Effects of enflurane anaesthesia and surgery on endocrine function in man. Acta anaesth. scand. Suppl. 7l: 32(1979).

6. Rudd, B. T., Cowper, J. M. \& Crawford, N. The determination of plasma free hydrocortisone and corticosterone by a combined fluorimetric and modified Porter-Silber procedure. Clin. Chim. Acta. 6: 686 (1961).

7. Mayes, D. Furuyama, S., Kem, D.C. \& NuGENT, C.A. Radio-immunoassay for plasma aldosterone. J. Clin. Endocr. 30: 682 (1970).

8. Schalch, D.S., \& Parker, M.L. A sensitive double antibody immunoassay for human growth hormone in plasma. Nature 203: 1141 (1964).

9. Moran, C.R. \& Lazarow, A. Immunoassay of insulin, two antibody system. Diabetes 12: 115 (1963).

10. JenSEN, H.K. \& Blichert-Toft, M. Serum corticotropin, plasma cortisol and urinary excretion of 17-ketogenic steroids in the elderly. Acta Endocri. 66: 25 (1971)

11. JLensen, H.K. \& Blichert-TOFT, M. Investigation of pituitary-adrenocortical function in the elderly during standarized operations and postoperative intravenous metyrapone test assessed by plasma cortisol, plasma compound and eosinophil cell determinations. Acta Endocri. 67: 495 (1971).

12. Bowen, D.J. \& RiChardson, D.J. Adrenocortical response to major surgery and anaesthesia in elderly patients. Brit. J. Anaesth. 46: 873 (1974). 
13. Oyama, T., Taniguchi, K., Jin, T., Satone, T. $\&$ KUDO, T. Effects of anaesthesia and surgery on plasma aldosterone concentration and renin activity in man. Brit. J. Anaesth. SI: 747 (1979).

14. Oyama, T., Takazawa, T. \& Kamada, M. Effect of halothane anaesthesia and surgery on human growth hormone and insulin levels in plasma. Clin Endocr. (Tokyo) 18: 47 (1970).

\section{RÉSUMÉ}

Les effets sur la fonction endocrinienne d'une anesthésie à l'halothane-protoxyde d'azoteoxygène et de la chirurgie abdominale ont été étudiés chez 18 malades âgés de 65 à 77 ans (moyenne: 69 ans). Les taux de cortisol plasmatique se sont élevés de façon significative au cours de l'anesthésie et de la chirurgie; les élévations observées étaient légerement plus importantes que celles trouvées chez les jeunes adultes. L'aldostérone plasmatique s'est également élevé. Les taux d'insuline plasmatique étaient plus bas que ceux des jeunes adultes et n'ont pas changé.

Les rêponses endocriniennes chez les malades âgés étant semblables en importance à celles des jeunes adultes, une thérapie hormonale spéciale n'apparait donc pas nécessaire chez eux lors des interventions habituelles. 